\title{
Guidance on breastfeeding during the Covid-19 pandemic
}

\author{
DValdenise Martins Laurindo Tuma Cali1 \\ (D) Vera Lucia Jornada Krebs² \\ (D) Werther Brunow de Carvalho ${ }^{3}$
}

\begin{abstract}
1. Doutora em Medicina pela Faculdade de Medicina da Universidade de São Paulo (FMUSP), médica pediatra e neonatologista do Instituto da Criança do Hospital das Clínicas da FMUSP, São Paulo, SP, Brasil. 2. Professora livre-docente em Pediatria pela FMUSP, médica pediatra e neonatologista do Instituto da Criança do Hospital das Clínicas da FMUSP, São Paulo, SP, Brasil.
\end{abstract} 3. Professor Titular do Departamento de Pediatria da FMUSP, área de Neonatologia/Terapia Intensiva, São Paulo, SP, Brasil.

http://dx.doi.org/10.1590/1806-9282.66.4.541

\section{SUMMARY}

OBJECTIVE: These recommendations aim to provide guidance on breastfeeding for mothers with suspected or confirmed Covid-19.

METHODS: We performed a review of the recent medical literature on breastfeeding mothers with suspected or confirmed Covid-19, focusing on the neonatal period.

RESULTS: We analyzed 20 recent publications on breastfeeding, Covid-19, and its transmission through breastmilk. We presented possible options for breastfeeding and their consequences for the mother and the child.

CONCLUSION: All maternal decisions in relation to breastfeeding are justifiable since the infection by Covid-19 is still poorly known. However, puerperal women and their families must be very well informed to make a conscious choice based on the information available in the literature so far.

KEYWORDS: Infant, newborn. Breastfeeding. Neonatology. Coronavirus. COVID-19.

\section{INTRODUCTION}

The impact of infections by the new coronavirus (Covid-19) has been increasing rapidly as the pandemic spreads and the number of patients affected grows exponentially.

The repercussions of this infection for pregnant women and newborns (NB) are still not well known, with sparse scientific evidence about its behavior in mothers and children. Reports and case series from the first epicenter of the epidemic, China, suggest that, unlike other infections caused by coronaviruses and the H1N1 virus, the effect in pregnant women is similar to that of adults of the same age group ${ }^{1-3}$. There is no evidence of greater clinical severity during pregnancy, nor of a higher prevalence of obstetric complications in patients infected by Covid-193-5. A study that included nine patients with pneumonia caused by Covid-19 did not find the presence of the virus in samples of six patients, collected from amniotic liquid, blood from the umbilical cord, breastmilk, and oropharynx swab of the $\mathrm{NB}^{3}$. Thus, the existing data 
so far, although not very solid from a scientific point of view, suggest that the main route of transmission of Covid-19 to neonates is by infected droplets from caregivers or, secondarily, through contact with contaminated biological material. The vertical mother-fetus transmission seems to be possible but is not documented, neither seems to be frequent. Zeng et al. ${ }^{6}$ reported 33 newborns of mothers infected by Covid-19 who showed mild to moderate signs and symptoms of early neonatal infection. Three of these NB presented molecular tests positive for Covid-19, and the authors questioned the existence of possible vertical transmission of the virus since all measures recommended for infection control were adopted. However, the samples of amniotic fluid, umbilical cord blood, and breastmilk did not show the presence of the virus.

In the face of the existing evidence so far, the concerns regarding the care of newborns whose mother have a suspected or proven infection by Covid-19 is focused on two aspects: 1) avoiding the infection of NB after birth, and 2) avoiding the infection of health professionals present in the delivery room and neonatal unit ${ }^{1.2}$.

On the other hand, the Chinese consensus is contrary to the evidence available; they have affirmed the possibility of vertical transmission of the new coronavirus and through breastmilk; for this reason, they recommend separating the mother and child and interrupting breastfeeding, even in suspected cases. In their publications, they advise that breastfeeding and/or extraction of breast milk are allowed only in the case of a negative PCR test for Covid-19 in the mother and breastmilk ${ }^{4}$. Thus, if these tests are not negative, the NB should be fed with breastmilk from a donor and/or formula.

\section{PROTOCOLS AVAILABLE FOR GUIDANCE ON BREASTFEEDING FOR MOTHERS WITH SUSPECTED OR CONFIRMED COVID-19}

Two reviews, one by the North-American Centers for Disease Control and Prevention ${ }^{7}$ and another by the Royal College of Obstetricians and Gynaecologists, London ${ }^{8}$, concluded that if the mother is willing and in clinical conditions to breastfeed her child, she must be well-informed and agree with the preventive measures necessary. The initiation and continuation of breastfeeding must be determined by the puerperal woman, along with their families and health professionals.
Recently, Eidelman A. made a contribution along the same line, stating that: "given the fact that mothers infected with the coronavirus have probably already colonized their babies, and ongoing breastfeeding has the potential to transmit protective maternal antibodies to infants through breastmilk. Therefore, breastfeeding should continue with the mother carefully washing her hands and wearing a mask during the procedure in order to minimize the NB's additional viral exposure".

Based on the evidence available and the recommendations listed above, the Brazilian Federation of the Gynecology and Obstetrics Associations (Febrasgo) published a note highlighting that the benefits of breastfeeding outweigh any potential risks of virus transmission through breast milk ${ }^{10}$. Therefore, they recommended that women infected by Covid-19 who wish to breastfeed should be encouraged to do so $^{10}$.

The World Health Organization (WHO) ${ }^{11}$, the Ministry of Health ${ }^{12.13}$, the Secretary of Health of the State of São Paulo ${ }^{14}$, the Brazilian and Global Network of Human Milk Banks ${ }^{15}$, the Pediatrics Society of São Paulo ${ }^{16.17}$, the Brazilian Society of Pediatrics ${ }^{1.2}$ and the American Academy of Pediatrics ${ }^{18}$, considering that mothers infected with the new coronavirus have probably already colonized their children, the benefits of breastfeeding for the health of the child and women ${ }^{19}$, and the absence of scientific evidence on the transmission of Covid- $19^{3}$ and other respiratory viruses ${ }^{7}$ through breastfeeding, recommend that breastfeeding is maintained with the necessary precautions in case of infection by Covid-19; this guidance is valid only if the mother wishes to breastfeed her child and is in clinical conditions to do so. Skin-to-skin contact in the delivery room and breastfeeding within the first hour of life should be suspended. Puerperal women and their NBs can stay in the same room, provided they are asymptomatic, there is a distance of 2 meters between the maternal bed and the NB cradle, and all the safety precautions described below are observed ${ }^{12-14}$. If the woman does not feel safe to breastfeed while infected, it is recommended that their milk is extracted and offered to the child.

It is recommended, therefore, that the precautions ahead are followed since an infected mother can pass the virus through respiratory droplets when in contact with the child, including during breastfeeding::12-15

- Washing hands for at least 20 seconds before touching the baby or extracting breastmilk (manual extraction or by pump). 
- Wearing a face mask (completely covering the nose and mouth) and avoiding talking or coughing during breastfeeding.

- Immediately changing masks in case of coughing or sneezing, or at every feeding.

- In the case of manual or mechanical extraction of human milk, strictly observe the guidelines available in the document: http://bvsms.saude. gov.br/bvs/publicacoes/cartilha_mulher_trabalhadoraamamenta.pdf. If possible, ask for help from a trained professional of the Human Milk Bank.

- Strictly follow the recommendations for cleaning the pumps for milk extraction after each use according to the manufacturer's specifications.

- Consider the possibility of asking for help from someone who is healthy to feed the newborn with the breastmilk using a cup or spoon.

- It is necessary that the person who will feed the NB with breastmilk learns how to do this with the help of a healthcare professional.

\section{CONSEQUENCES OF MATERNAL CHOICES IN RELATION TO BREASTFEEDING}

As described above, mothers with suspected or confirmed Covid-19 may, after receiving all necessary information, choose to breastfeed their NBs, extract the breast milk and ask a professional or healthy companion to feed it to the NB, or even not to feed the child breastmilk. Whatever the choice, it should be respected without reprimands. Puerperal women are often going through a very difficult time, fragile, afraid of their diagnosis, and the consequences it might ensue. They will always choose what they think is best for their child. Thus, their choice reflects their state of mind and should be heeded, whatever it is.

\section{A. Option for starting and maintaining breast- feeding}

This is a WHO recommendation", which must be respected provided the mother and NB are in good clinical conditions. The mother should be encouraged to breastfeed her child, always complying with the protection standards described above; it is essential she receives all the support and guidance necessary from the multi-professional team, including regarding mental health, in this particularly difficult time. The presence of a healthy companion is allowed, but must not of visitors; this tends to be a cause of sorrow for the mother because she is not able to share her happiness and worries with other family members.

Breastfeeding protects against morbidity and mortality in the neonatal and post-neonatal periods, as well as throughout childhood. Its benefits extend also to adolescence and adulthood and include the prevention of dental malocclusion, overweight and obesity, allergic and chronic diseases. It also favors the bond between mother and child, provides higher intellectual coefficients, and greater professional success, with higher monthly incomes in the future ${ }^{11,18-20}$.

Regarding immunological protection, its effect is particularly important against infectious diseases that benefit from the direct transfer of antibodies and other anti-infectious factors, favoring also the lasting transfer of immunologic competence and memory ${ }^{11.19}$.

We must not forget, also, of the protection conferred by breastfeeding to the maternal health, providing less postpartum bleeding, aiding in the reduction of weight gained during the pregnancy, reducing the risk of breast and ovarian cancer, diabetes type 2 , and postpartum depression. Exclusive breastfeeding also provides a contraceptive effect which assists in the spacing between pregnancies, even when no other method is used for such purposes ${ }^{19.20}$.

The contact between mother and child during breastfeeding will certainly benefit her from an emotional point of view, providing the necessary support to cope with this difficult period of quarantine and social isolation. The mother should be well-informed about the absence of data, so far, that proves vertical transmission and infection through breast milk ${ }^{3.6}$. On the other hand, there are reports of cases in which the NB contracted the disease, usually with a not severe presentation, through respiratory droplets from the mother or health professionals; hence the importance of, at all times, complying with the protection practices during the period of viral transmissibility ${ }^{3-6}$.

\section{B. Option for not breastfeeding and extracting breastmilk}

Women who are not in good clinical conditions or who do not feel safe to maintain direct contact with their child should opt for the extraction of breastmilk and get help from a trained professional to feed the NB using a cup or spoon or instruct a healthy companion on how to do so. The extraction of milk should also be an option when the NB is premature, or even when they are not in clinical conditions that allow sharing the same room. 
The raw milk must be extracted in an isolated room, preferably with the aid of a trained professional of the Human Milk Bank (HMB), and can be stored for up to 12 hours in the refrigerator. The milk extracted from mothers with a suspected or confirmed Covid19 infection should not be kept inside the HMB; the fridge must be located outside and exclusive, although there is no evidence of viral excretion in breast milk.

It is important that mothers are aware of the importance of providing their milk to the NB, and professionals should inform them of all the benefits listed above. It is also recommended that the mother be informed of the frequency of extraction, i.e., four to six times a day or more, to maintain milk production until the end of isolation ${ }^{12-15}$.

\section{OPTION FOR NOT BREASTFEEDING AND NOT EXTRACTING BREASTMILK}

Women may fear transmitting the virus to the NB, both by contact and through breastmilk; they also may not yet be in clinical conditions to breastfeed or extract their milk. In this situation, they will be separated from their child, who will not be offered their milk during the period of isolation. Such an option, if maintained after clarification by professionals, should be respected.

As reported above, the Chinese consensus is to separate the mother from the child and interrupt breastfeeding, even in suspect cases. Breastfeeding and/or the extraction of breast milk are allowed only in the case of negative PCR tests for Covid-19 in the mother and breastmilk ${ }^{4}$. Thus, if these tests are not negative, the NB should be fed with breastmilk from a donor and/or formula. In Brasil, according to the protocols described above, the recommendation is different, but the will of the mother is paramount and must be accepted.

Once again it is recommended to inform the mother on the frequency of at least four to six daily extractions to maintain the milk production until the cure of the infectious process; this milk will, unfortunately, be discarded ${ }^{15}$.

The NB will be separated from the mother and, during the period recommended, will be preferably supplied with breast milk from a healthy donor. A bottle should not be used for the administration of milk, if possible, so that there is the possibility of resuming breastfeeding after the isolation period; the use of a cup or spoon is recommended. A nasogastric tube is used in premature NBs (with gestational age less than 34 weeks) or with respiratory insufficiency. It is known that the donor milk can only be offered to the NB after pasteurization; although this process maintains the nutritional value of the milk, it reduces its immunological properties by about $30 \%$ to $40 \%$. Regarding its nutritional components, only lipase and some thermolabile vitamins are inactivated in pasteurized milk ${ }^{15.18}$.

We must highlight here the importance of Human Milk Banks. In Brasil, there are approximately 225 Human Milk Banks and 212 Units of Human Milk Collection, which provide donor milk for NBs who do not receive milk from their own mothers. These numbers are growing because the Brazilian Network, which served as a basis for the implementation of the Global Network of Human Milk Banks, is very active and recognized at a world level (https://rblh. fiocruz.br $)^{15}$. We are in the final stage of implementing a Human Milk Bank in the Neonatal Center of the Children's Institute of Hospital das Clínicas and the Faculty of Medicine of the University of São Paulo, which is likely to become a reference in Brasil and abroad. The project should be completed shortly, by the end of 2020.

The offer of the pasteurized donor milk is a valid option in the situations mentioned above, much better than the administration of formula. This features nutritional elements that are not always suitable for the nutrition of NB, proteins that form bigger curds of difficult digestion and provide immunological factors $^{19}$. There is also the possibility of, after a single ingestion of formula, the NB developing cow's milk protein allergy. We also have to consider the cost of the product, often inaccessible for Brazilians with low purchasing power and difficulty to work in the current scenario we are going through ${ }^{20}$.

There is the possibility of weaning if the precautions mentioned above are not taken. Milk production may decrease gradually if the frequency of extraction is not maintained; the NB may become accustomed to the bottle nipple and, thus, refuse the mother's breast when breastfeeding is attempted. Walters et al. ${ }^{20}$, in 2019, published an article that describes the billionaire costs of not breastfeeding. The research was conducted for six years, in more than 100 countries. The absence of breastfeeding and the interruption of exclusive breastfeeding in the first six months led to, according to their calculations, the loss of 341.3 billion dollars annually due to childhood 
diseases and deaths, loss of productivity by early mortality, cognitive loss in children who were not breastfed, maternal deaths due to diabetes, breast cancer, and ovarian cancer. We should also include the thousands of cases of childhood obesity, which also increase morbidity and mortality. The authors completed the study by stating that "the human and financial costs of not breastfeeding highlight the importance of fostering a culture that supports breastfeeding at a global scale."
Considering everything that has been exposed, it can be concluded that all the options regarding breastfeeding are justifiable since the infection by Covid-19 is still very new and little known. However, puerperal women and their families must be very well informed to make a conscious choice based on the information available in the literature so far.

\section{Author contributions}

All authors contributed equally to this study.

\section{RESUMO}

OBJETIVO: Estas recomendações têm como objetivo orientar o aleitamento materno de mães com Covid-19 suspeita ou confirmada.

MÉTODO: Foi realizada revisão da literatura médica recente sobre aleitamento materno de mães com Covid-19 suspeita ou confirmada, focando o período neonatal.

RESULTADOS: Foram analisadas 20 publicações recentes sobre aleitamento materno, Covid-19 e sua transmissão pelo leite. Foram apresentadas as possiveis opções maternas em relação ao aleitamento e suas consequências para o binômio mãe-filho.

CONCLUSÃo: Todas as opções maternas em relação à amamentação são justificáveis, porque a infecção por Covid-19 ainda é pouco conhecida. Porém, as puérperas e seus familiares devem ser muito bem orientados, realizando uma opção consciente e baseada nas informações disponíveis na literatura até o momento.

PALAVRAS-CHAVE: Recém-nascido. Aleitamento materno. Coronavírus. Neonatologia. Covid-19.

\section{REFERENCES}

1. Sociedade Brasileira de Pediatria. O aleitamento materno nos tempos de COVID-19. [cited 2020 Abr 10]. Available from: https://www.sbp.com.br/ fileadmin/user_upload/22393c-Nota_de_Alerta_sobe_Aleitam_Materno_ nos_Tempos_COVID-19.pdf

2. Sociedade Brasileira de Pediatria. Prevenção e abordagem da infecção por COVID-19 em mães e recém-nascidos, em hospitais-maternidades. [cited 2020 Abr 10]. Available from: https://www.sbp.com.br/imprensa/detalhe/ nid/prevencao-e-abordagem-da-infeccao-por-covid-19-em-maes-e-recem-nascidos-em-hospitais-maternidades/

3. Chen H, Guo J, Wang C, Luo F, Yu X, Zhang W, et al. Clinical characteristics and intrauterine vertical transmission potential of COVID-19 infection in nine pregnant women: a retrospective review of medical records. Lancet. 2020;395(10226):809-15

4. Wang L, Shi Y, Xiao T, Fu J, Feng X, Mu D, et al. Chinese expert consensus on the perinatal and neonatal management for the prevention and control of the 2019 novel coronavirus infection (First edition). Ann Transl Med. 2020;8(3):47-55

5. Lu Q, Shi Y. Coronavirus disease (COVID-19) and neonate: what neonatologist need to know. I Med Virol. 2020;92:564-7.

6. Zeng L, Xia S, Yuan W, Yan K, Xiao F, Shao J, et al. Neonatal early-onset infection with SARS-CoV-2 in 33 neonates born to mothers with COVID-19 in Wuhan, China. JAMA Pediatr. 2020;E1-E3. doi: 10.1001/ jamapediatrics.2020.0878.

7. Centers for Disease Control and Prevention (CDC). Interim considerations for infection prevention and control of coronavirus disease 2019 (COVID19) in inpatient obstetric healthcare settings. [cited 2020 Abr 10]. Available from: https://coronavirus.dc.gov/sites/default/files/dc/sites/coronavirus/ publication/attachments/Guidance\%20for\%20Pregnant\%20Women\%20 COVID19\%20\%281\%29.pdf
8. Royal College of Obstetricians and Gynaecologists. Coronavirus (COVID-19) infection in pregnancy. Information for healthcare professionals. Version 1: Published Monday 9 March, 2020. [cited 2020 Abr 10]. Available from: https://www.rcog.org.uk/globalassets/documents/guidelines/coronavirus-covid-19-virus-infection-in-pregnancy-2020-03-09.pdf

9. Mary Ann Liebert, Inc. Breastfeeding Medicine. Coronavirus treatment and risk to breastfeeding women. Press release [online]. New Rochelle: Mary Ann Liebert, Inc; 2020. [cited 2020 Abr 10]. Available from: https://home.liebertpub.com/news/ coronavirus-treatment-and-risk-to-breastfeeding-women/3662

10. Mariani Neto C. Nótula complementar sobre COVID-19 e aleitamento materno. FEBRASGO, 18 Março 2020. [cited $2020 \mathrm{Abr}$ 10]. Available from: https://www.febrasgo.org.br/pt/noticias/ item/949-notula-complementar-sobre-covid-19-e-aleitamento-materno

11. Organização Mundial de Saúde. COVID 19: recomendações da OMS para assegurar o contato mãe-bebê depois do parto e no aleitamento materno Instituto Europeu de Saúde Mental Perinatal. [cited 2020 Abr 10]. Available from: https://saudementalperinatal.com/covid-19-recomendacoes-daoms-para-assegurar-o-contato-mae-bebe-depois-do-parto-e-no-aleitamento-materno/.

12. Brasil. Ministério da Saúde. Atenção à saúde do recém-nascido no contexto da infecção pelo novo coronavírus. Nota Técnica № 6/2020-COCAM/ CGCIVI/DAPES/SAPS/MS. [cited 2020 Abr 10]. Available from: http:// www.crn2.org.br/crn2/conteudo/nt\%206.pdf

13. Brasil. Ministério da Saúde. Trata-se de avaliação de medida para o enfrentamento da situação de emergência em saúde pública decorrente do Coronavírus (Covid-19), sobre questionamento da Rede de Atenção à Saúde (RAS) respectivo à preservação da amamentação em situação de risco iminente de transmissão do respectivo vírus, em situações que a mãe 
apresente sintomatologia compatível com síndrome gripal. Nota Técnica No 7/2020-COCAM/CGCIVI/ DAPES/SAPS/MS. [cited 2020 Abr 10]. Available from: http://www.crn2.org.br/crn2/conteudo/nt\%206.pdf

14. Governo do Estado de São Paulo. Secretaria da Saúde do Estado de São Paulo. Nota Técnica no 3 de 31/03/2020. Manejo do ciclo gravídico puerperal e lactação-COVID-19. Diário Oficial do Estado no 63 de 31/03/2020; Seção 2:p.28.

15. Ministério da Saúde. Fundação Oswaldo Cruz. Rede Brasileira de Bancos de Leite Humano. Recomendação técnica No. 01/20.170320.COVID-19 e amamentação. Adaptada do Ministério da Saúde, não publicada.

16. Sociedade de Pediatria de São Paulo. Coronavírus e recém-nascido: o que se sabe até o momento? [cited 2020 Abr 10]. Available from: https://www. spsp.org.br/2020/03/30/coronavirus-e-recem-nascido-o-que-se-sabeate-o-momento-30-03-2020/
17. Sociedade de Pediatria de São Paulo. Recomendações para cuidados assistência ao recém-nascido com suspeita ou diagnóstico de COVID-19. [cited 2020 Abr 10]. Available from: https://www.spsp.org.br/2020/04/06/ recomendacoes-para-cuidados-e-assistencia-ao-recem-nascido-com-suspeita-ou-diagnostico-de-covid-19-06-04-2020/

18. Puopolo KM, Hudak ML, Kimberlin DW, Cummings J. Initial guidance: management of infants born to mothers with COVID-19. American Academy of Pediatrics Committee on Fetus and Newborn, Section on Neonatal Perinatal Medicine, Committee on Infectious Diseases. [cited 2020 Abr 10]. Available from: https://downloads.aap.org/AAP/PDF/COVID\%2019\%20 Initial\%20Newborn\%20Guidance.pdf

19. Victora CG, Bahl R, Barros AJ, França GV, Horton S, Krasevec|, et al. Breastfeeding in the 21st century: epidemiology, mechanisms, and lifelong effect. Lancet. 2016;387(10017):475-90.

20. Walters DD, Phan LTH, Mathisen R. The cost of not breastfeeding: global results from a new tool. Health Policy Plan. 2019;34(6):407-17. 